\title{
( Impact of Grameen Bank Microcredit on aße Standard of Living in Rural Poor Women in Sariakandi Upazila of Bogra District
}

\author{
Md. Abu Shamim \\ M. Phil Research Fellow, Department of Economics, Rajshahi University, Rajshahi, BANGLADESH \\ *E-mail for correspondence: shamim07eco@mail.com
}

No Conflict of Interest: Declared

\begin{abstract}
The standard of living in many developing countries like Bangladesh especially rural area is not standard level or satisfied. The microcredit programs of Grameen Bank (GB) in Bangladesh have emerged as a strategy on standard of living and reduction poverty. They are also trying to remove poverty and unemployment and energetic poor people who want to engage in economic activities, the institution provides not only loan to them but also advice and monitoring. The aim of the study is to explore the impact of GB microcredit on standard of living of rural women in study area whom have already involved in its loan. As sample only 198 current microcredit fund receiver's respondents from Sariakandi upazila under Bogra district were selected. Data were collected from six centers under two selected branches using questionnaire. Data were explained normally under descriptive method using simple statistical tools such as chi-square test and One-way ANOVA test and econometric model such as OLS regression. After analyzing data, results of the study show that there has a positive effect on savings, average monthly income, expenditure, average level of education of borrowers' households, number of income earner and asset. The results of One-way ANOVA test indicate that there exists a significant relationship among some factors of standard of living with amount of loan of GB and Chisquare test is proved that microcredit of GB has also a positive contribution on improving standard of living in study area.
\end{abstract}

Keywords: Grameen Bank, Microcredit, Standard of Living

\section{INTRODUCTION}

The economy of Bangladesh depends on mainly agriculture with huge people about 164 million and small area which is only 147570 square $\mathrm{Km}$. Most of them live in rural area and employ in agricultural sector and an insignificant part of them employ in non-farming activities. More than 63 million people live below the poverty line. According to BER-2014, the incident of poverty with respect to upper poverty line was 24.47 percent in 2014 which was 31.5 percent in 2010 and 40 percent in 2005. These poor people cannot provide to basic needs such as food, housing, clothing, education and treatment for earning insufficient money. They can also not buy quality full foods for their families. Monthly income and expenditure are also low. They do not also get loan facilities from government institution and conventional Bank due to insufficient and lack of required collateral. Because the financial market of Bangladesh is very poor but not stronger. A huge number of people is the potential of unemployed and underemployed people. So creation of self-employment in rural area is necessary very much. Landless people only sell his labor on other lands are faced various problems due to access to land and capital resources. A large number of rural poor is kept out of the institutional credit market. They depend on the informal source such as moneylenders. There the rate of interest is very high and this rate on the informal source is not constant but very it person to person. They have no access to formal sector for loan due to required collateral. According to World Bank Economic Review microfinance has not only helped poor people to develop in their material capital but also in the human capital, by better access to health care and education system, and general awareness among the people about their rights and duties towards society.

So government and non-government organization as well as Microfinance Institutions (MFIs) all are working to involve to poor people and unemployed people in economic activities and they are trying to eliminate poverty from the country. But amount of microcredit of 
government organizations is not enough for poor people in economic activities. There are many MFIs in Bangladesh such as Grameen Bank, BRAC, ASA, TMSS etc.

However, the poor people who want to work willingly and employed themselves in economic activities but they have not enough money in their hand. MFIs provide loan to the poor people for investment in handicraft, small holder farmers, food processors, petty business and other persons who drive micro-enterprises. As a microfinance institution, Grameen Bank by Nobel Prize Winner and professor Muhammad Yunus was established on October 1983. Microfinance institutions have been set up or established to fill up the gap created by the formal financial sector to improve the socio-economic condition of the poor people in rural area of Bangladesh.

Common of the purpose of the microcredit program is to provide microcredit to the rural poor people to employ themselves in economic activities. So that these people can contribute to increase in household income and help their families get free of poverty as well as improve their household condition and standard of living after involving with this program such as (Mahmood, at el., 2016; Weerasinghe and Dedunu, 2017) and negative result with (Morduch, 2000; Juanah, 2005; Coleman, 1999 and Okafor, 2016). This study is to try to find out the impact of microcredit programme of Grameen Bank on living standard in the study area.

\section{Objectives of the Study}

The main objective of the present study is to explore the impact of GB microcredit on standard of living of the rural poor people in study area. The above objective of the study are specified below-

- To measure the relationship between microcredit of GB and the standard of living of poor women;

- To examine the impact of Grameen Bank microcredit on the standard of living condition of poor women;

\section{Hypothesis of the Present Study}

The following hypothesis has been tested

Ho: There has no significant impact of Grameen Bank microcredit on standard of living in rural poor women.

$\mathrm{H}_{1}$ : There has significant impact of Grameen Bank microcredit on standard of living in rural poor women.

\section{LITERATURE REVIEW}

Previous many studies have been shown that microfinance is a potential solution to poverty reduction in which standard of living is one of the indicators (Yunus, 1999). It has been conducted the study which attempted to assess the impact of microfinance on living standards, empowerment and poverty alleviation of poor people. Most of the women began petty business by taking loan from MFIs. But about 84 percent respondents of MFIs are women and most of them are only completed primary education. It has been shown that microfinance has a positive impact on the standard of living of the poor people (Khan and Rahman, 2007). The study shows that the microcredit is a tool for poverty reduction in rural area through microcredit program. The microcredit program of Jagoroni Chacra Foundation has a positive impact to the rural poor to improve their income and other social economic conditions. The income of sixty percent respondent has increased after receiving microcredit (Haque, 2012). Rural women are the most deprived section of the society and a big part of them are extremely poor. MFIs have a contribution on poverty alleviation in the study area by creating income generation activities and self-employment opportunities for the poor people by providing microcredit (Ahmed et al., 2011). It has been explained the impact of microcredit on income generation capacity of women in the Tamale Metropolitan Area of Ghana. Beneficiary women are empowered to engage in income generation activities than the preserve of men. But it is mentioned that women's participation in decision making at the household and community levels in the study area is not significantly changed which is dominated by male society (Alhassan and Akudugu, 2012). It has been explored that the change in livelihood status scores of the respondent's beneficiaries who involved in microcredit of varied from 4 to 24 . The average change in livelihood status scores of the respondents was 13.94. Results on change of livelihood status in three dimensions namely (a) change of farm and household materials (b) change of housing, health and sanitation and (c) change if annual family income in terms of after involvement with GB were shown positively significant (Kuhinur and Rokonuzzaman, 2009). It is found a positive relationship between Microfinance Bank and standard of living of hairdressers in study area. Most of the respondents received microcredit from these banks for their business expansion. Majority of the microfinance bank in study area follow the same method as the Grameen Bank of Bangladesh. The respondents felt some problems such as the short time of repayment, meaningful invested before the repayment, insufficient loan, and high the rate of interest (Abiola and Salami, 2011). It has been examined an impact of microcredit borrowing on household consumption from the selected microfinance institution in Bangladesh. An increase in the amount borrowed has a positive effect on per capita household consumption (Schrieder, 2014). The effect of microcredit programs on the standard of living of poor household in Bangladesh has been explored. There has a positive impact on per-capita food expenditure, land holding and women's ownership of non-land assets and has no significant impact on overall household non-land asset accumulation and educational attainment (Fattah, 2014). The performance of four of the biggest microcredit institutions in Bangladesh using survey method the total respondents two hundred who have borrowed from these institutions has been analyzed. It shows that microcredit programs of these institutions 
have a positive impact on food consumption, health, household expenditure and standard of living (Islam et al., 2013). A comparative study on evaluation of microcredit in Bangladesh has been examined. He shows a sharp reduction in the number of GB's members living below the poverty line (20\%) compared to non-borrowers (56\%) (Ali, 2008). It has been explained a positive impact of microcredit program participation on household expenditure and children's education in Pakistan (Noreen et al., 2011). It has been explored the impact of microfinance bank on standard of living in the study. There is a significant relationship between microfinance and standard of living (Olusanya and Olumuyiwa, 2012).

\section{Microfinance InStitution as Grameen BanK AND STANDARD OF LIVING}

Standard of living is strongly connected to the quality of life. Income or expenditure is a significant factor of living standard of the borrowers of GB who are the poor people. Income and expenditure are also related each other. So income is one of significant factor of living standard of the poor people as well as savings (Khan and Rahman, 2007). Due to low income, poor people do not provide of basic human needs, including food, safe drinking water, sanitation facilities, health, shelter and education, etc. GB provides microcredit to poor people who want to engage themselves in income generating activities. They have no access to conventional bank due to lack of required collateral. So it shows how microfinance works, to reduce poverty and how it affects the living standard (income, saving etc.) of the poor people in Bangladesh (Khan, and Rahman; 2007). After receiving loan, they get opportunity to increase employment through beginning petty business, buying auto rickshaw and cultivating crops in case of leasing land. It is shown that microfinance has a significantly increased the income of poor households and improving the living standards, the impact on productive activities is higher compared to the consumption (Mahmood et al.; 2016). However, it usually helps to increase borrowers' income, savings and consumption expenditure, to attain more of children's education and to improve housing condition and medical treatment. Microfinance increases income and savings which help to improve the lifestyle and living standard of the poor (Kisto, 2014). Observe that microcredit helps the poor create and increase income. To the extent of the poor creating income, their standard of living increase (Idalor and Imhanlatrimi, 2011).

Income is considered as one main proxy for poverty and expenditure is also other main proxy of living standards respectively (Mahmood et al.; 2016). Income and expenditure are also related with consumption. The level of income and consumption is main determinants the living standard and quality of life. Almost all the borrowers reported an increase in their incomes which has improved their standard of living (Chirkos; 2014).

\section{SElection OF Study AREA}

Sariakandi upazila under Bogra district of Rajshahi division in Bangladesh as a study area has been selected randomly but Bogra district has been selected purposively. In this study, both primary and secondary data have been used but primary data have mainly been used to analyze for regression of the study. Sariakandi Upazila has a total area of 408.50 square kilometres (157.72 sq mi). About three-fifths is land and two-fifths is water, mainly the Jamuna River, which flows south through the upazila. The thana was formed in 1886 and it was turned into a municipality in 1999. According to the 2011 Bangladesh census, there were lived in 75614 households and 270719 populations of whom male and female are 122442 and 117641 respectively, only $6.8 \%$ of whom lived in urban areas. Literacy rate by both sex in the upazila was $32.3 \%$ in 2001 while male and female were separately $37.1 \%$ and $27.3 \%$ and raised to $36.9 \%$ in 2011 while the rate literacy of male and female $40.4 \%$ and $33.4 \%$ respectively. In case of land distribution, the ownership of agricultural landowner and landless are $56.61 \%$ and $43.39 \%$ respectively. Main sources of income are agriculture, non-agricultural labourer, industry, commerce, service, transport and communication. Main crops are paddy, jute, wheat, mustard and vegetables. There are two centers under two branches namely Sariakandi and Fulbari branches. The two branches are indentified on the map of sariakandi upazila that is presented below.

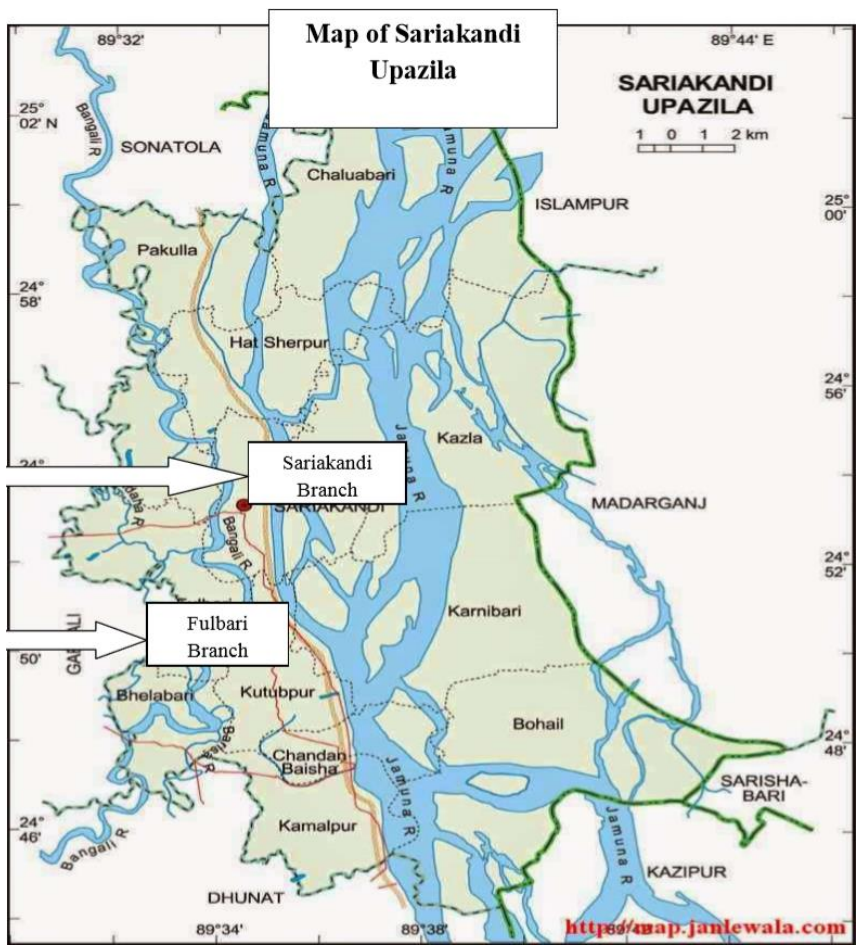

\section{Methodology}

Primary data have been collected from 198 respondents who have been involved with microfinance of Grameen Bank at least four years ago through interview method using questionnaires. In this study, qualitative and 
quantitative data have been also used for data analysis. To achieve this study objective, both statistical and econometrics analysis are used to explore the impact of the microfinance of GB on living standard. As statistical method, Chi-square test has been used to achieve first objective where data have been collected from the borrowers of GB following the five Likert scales such as strongly agree (SA), strongly disagree (SA), agree (A), disagree (DA) and undecided (UD) following (Abiola and Salami; 2011). The formula of chi-square can be written such

$\chi^{2}$ cal $=\sum_{i=1}^{8} \sum_{j=1}^{5}\left(\frac{\left(O_{i j}-E_{i j}\right)^{2}}{E_{i j}}\right)$

Where $E_{i j}=\frac{R_{i} \times C_{j}}{n}=\frac{R T \times C T}{n}$

Where, $\mathrm{E}_{\mathrm{ij}}$ is expected frequency; $\mathrm{O}_{\mathrm{ij}}$ is observed frequency; $i$ and $j$ are row and columns; RT and CT are row total and column total respectively and $n$ is ground total. Degree of freedom (df) is (r-1) (c-1).

On the other hand, OLS regression is also used to achieve second objective. Expenditure is one main factor of living standard (Mahmood et al., 2016). Expenditure is not influence only amount of microcredit from GB but also other factors that is formulated as follows:

$E_{i}=f\left(X_{i}\right)$

Where, $\mathrm{E}_{\mathrm{i}}$ is average monthly expenditure of borrowers of GB which is continuous variable and $X_{i}$ is a set of socioeconomic factors that influence expenditure of borrowers. Where average monthly expenditure (AEXPEN) is dependent variable and explanatory variables are total savings $\left(\mathrm{TSAV}=\beta_{1}\right)$; amount of loan from GB $\left(\mathrm{LON}=\beta_{2}\right)$; family size $\left(F S=\beta_{3}\right)$; average level of education $($ AEDU $=$ $\left.\beta_{4}\right)$; average monthly income (AINC $=\beta_{5}$ ); number of income earner $\left(E R N R=\beta_{6}\right)$ and land size $\left(L A N=\beta_{7}\right)$. On the basis of the above factors, a specified linear regression can be written as given below:

$E_{i}=\beta_{0}+\beta_{i} X_{i}+\mu_{i}$

$E_{i}=\beta_{0}+\beta_{1} \mathrm{X}_{1}+\beta_{2} \mathrm{X}_{2}+\beta_{3} \mathrm{X}_{3}+\beta_{4} \mathrm{X}_{4}+\beta_{5} \mathrm{X}_{5}+\beta_{6} \mathrm{X}_{6}+\beta_{7} \mathrm{X}_{7}+\mu$

The above (3) equation is estimated by OLS regression method. In addition, ANOVA test has been also used for searching statistically significant association between amount of loan and other important factors of living standard.

\section{REsults AND Discussion}

In this section, results of chi-square test for hypothesis and OLS regression have been discussed that has been presented below:

\section{Results for hypothesis test}

The results of data analysis of borrowers' report are found in table in 1.1 that about 72.2 percent of the borrowers have answered strongly agree that their savings has been increased at present. There are two types of savings such as mandatory and voluntary savings. Due to the obligatory imposed for mandatory savings by institutions, they are bound to keep an amount of deposited money in any financial institution is defined as obligatory savings. Income and household asset of borrower's households have also been increased that 75.3 percent and 80.6 percent of the borrowers have strongly agree and the lowest percent of borrowers are undecided that is 0.5 percent of increase income and 1.0 percent of increase asset respectively.

Table 1: Data Analysis of Borrower's Report

\begin{tabular}{|l|l|l|l|l|l|l|l|l|l|l|l|l|}
\hline & \multicolumn{3}{|l|}{ SA } & SD & A & D & U & \\
\hline Variables & Freq. & $\%$ & Freq. & $\%$ & Freq. & $\%$ & Freq. & $\%$ & Freq. & $\%$ & Total \\
\hline Savings has increase & 143 & 72.2 & 6 & 3.0 & 32 & 16.2 & 9 & 4.5 & 8 & 4.0 & 198 \\
\hline Income has increase & 149 & 75.3 & 6 & 3.0 & 35 & 17.7 & 7 & 3.5 & 1 & 0.5 & 198 \\
\hline Interest rate & 0 & 0 & 63 & 31.8 & 4 & 2.0 & 111 & 56.1 & 18 & 9.2 & 196 \\
\hline Employment opportunities & 172 & 86.9 & 4 & 2.0 & 19 & 9.6 & 3 & 1.5 & 0 & 0 & 198 \\
\hline Asset has increase & 158 & 80.6 & 6 & 3.1 & 24 & 12.1 & 6 & 3.1 & 2 & 1.0 & 196 \\
\hline Loan procedure & 183 & 92.4 & 3 & 1.5 & 9 & 4.5 & 3 & 1.5 & 0 & 0 & 198 \\
\hline Average Education level & 77 & 39.1 & 33 & 16.8 & 62 & 31.5 & 14 & 7.1 & 11 & 5.6 & 197 \\
\hline
\end{tabular}

Source: Calculation from Field Survey, 2017

It is shown in above table 1 that average education level of borrowers' households has improved at present. Because GB provides education loan among the borrowers' children and it has a contribution on improvement of children education. Borrowers of GB are not satisfied on the rate of interest that 56.1 percent of borrowers are disagree. The rate of interest is high. After receiving credit from GB, borrowers have employed more themselves in income generating activities such as non-farming activities. Due to increase self- employment and engage themselves more in non-farming activities, their income and assets have been increased at present. About 92.4 percent of borrowers are agree that loan procedure of GB is more easily compared to any Government bank and MFIs. On the other hand, the calculated value of $\chi^{2}$ is calculated following quantitative variables such as savings, income, interest rate, employment, assets, loan procedure and average education level that has been shown in table 2 . 
Table 2: Data Analysis of Borrower's Responses

\begin{tabular}{|l|c|c|c|c|c|c|c|c|c|c|c|c|}
\hline & \multicolumn{3}{l}{$\mathrm{SA}$} & \multicolumn{2}{l|}{$\mathrm{SD}$} & \multicolumn{2}{l|}{$\mathrm{A}$} & $\mathrm{D}$ & $\mathrm{U}$ & \\
\hline Variables & $\mathrm{A}_{1}$ & $\mathrm{E}_{11}$ & $\mathrm{~A}_{2}$ & $\mathrm{E}_{12}$ & $\mathrm{~A}_{3}$ & $\mathrm{E}_{13}$ & $\mathrm{~A}_{4}$ & $\mathrm{E}_{14}$ & $\mathrm{~A}_{5}$ & $\mathrm{E}_{15}$ & Total \\
\hline Savings has increase & 143 & 126.456 & 6 & 17.348 & 32 & 26.524 & 9 & 21.936 & 8 & 5.735 & 198 \\
\hline Income has increase & 149 & 126.456 & 6 & 17.348 & 35 & 26.524 & 7 & 21.936 & 1 & 5.735 & 198 \\
\hline Interest rate & 0 & 125.179 & 63 & 17.173 & 4 & 26.256 & 111 & 21.715 & 18 & 5.677 & 196 \\
\hline Employment opportunities & 172 & 126.456 & 4 & 17.348 & 19 & 26.524 & 3 & 21.936 & 0 & 5.735 & 198 \\
\hline Asset has increase & 158 & 125.179 & 6 & 17.173 & 24 & 26.256 & 6 & 21.714 & 2 & 5.677 & 196 \\
\hline Loan procedure & 183 & 126.456 & 3 & 17.348 & 9 & 26.524 & 3 & 21.936 & 0 & 5.735 & 198 \\
\hline Average Education level & 77 & 125.817 & 33 & 17.261 & 62 & 26.390 & 14 & 21.825 & 11 & 5.706 & 197 \\
\hline Total & 882 & & 121 & & 185 & & 153 & & 40 & & 1381 \\
\hline
\end{tabular}

Source: Calculation from Field Survey, 2017

$$
\begin{aligned}
& \mathrm{df}=(\mathrm{r}-\mathrm{c})(\mathrm{c}-1)=(7-1)(5-1)=6 \times 4=24 \\
& E_{11}=\frac{198 \times 882}{1381}=125.179 \\
& \chi^{2} \mathrm{cal}=\sum_{i=1}^{8} \sum_{j=1}^{5}\left(\frac{\left(O_{i j}-E_{i j}\right)^{2}}{E_{i j}}\right) \\
& \chi^{2} \mathrm{cal}=\left(\frac{(143-126.456)^{2}}{126.456}\right)+\ldots \ldots \ldots \ldots . . .+\left(\frac{(11-5.706)^{2}}{5.706}\right) \\
& =948.257
\end{aligned}
$$

The calculated value of $\chi^{2}$ is 948.257 which is more than the table value 42.980 represent at $1 \%$ significant level. It indicates that microfinance of GB has a significant and positive contribution on standard of living in rural area among their borrowers.

On the other hand, second objective of this study is to determine the impact of microfinance of GB on living standard in the study area following quantitative variable. Descriptive analysis of dependent and explanatory variables are presented in table 3 that has been analyzed such as mean, standard deviation, minimum and maximum value of the variables.

Table 3: Descriptive of Variable Analysis of Sample at Present

\begin{tabular}{|c|c|c|c|c|c|}
\hline Variable & $\mathrm{N}$ & Minimum & Maximum & Mean & Std. Deviation \\
\hline \multicolumn{7}{|c|}{ Dependent Variable } \\
\hline AEXPEN & 198 & 1000.00 & 11433.00 & 4408.79 & 2101.52 \\
\hline \multicolumn{7}{|c|}{ Explanatory Variable } \\
\hline TSAV & 198 & 850.00 & 8440.00 & 3404.29 & 1801.81 \\
\hline LON & 198 & 9000.00 & 70000.00 & 24585.86 & 9960.37 \\
\hline FS & 198 & 2.00 & 6.00 & 3.23 & 1.19 \\
\hline AEDUC & 198 & 1.00 & 9.00 & 3.41 & 1.48 \\
\hline AINCM & 198 & 1350.00 & 15666.67 & 4896.67 & 2394.89 \\
\hline EARNER & 198 & 1.00 & 5.00 & 1.73 & 0.86 \\
\hline LAN & 198 & .00 & 130.00 & 38.10 & 43.99 \\
\hline
\end{tabular}

Source: Calculation from Field Survey, 2017

The results of descriptive analysis show that the lowest and highest average monthly expenditure of borrowers are Tk. 1000 and Tk. 11433.00 and mean value of average monthly expenditure is Tk. 4408.79 while lowest and highest average monthly income are Tk.1350.00 and Tk. 15666.67 respectively and mean value of average monthly income is Tk. 4896.67.

The loan amount distribution of highest, lowest and mean value among the borrowers is Tk. 9000.00, Tk.70000.00 and Tk. 24585.86 in yearly while minimum, maximum and mean value of total savings or cumulative savings of borrowers are Tk. 850, Tk. 8440.00 and 3404.29 respectively. On the other hand, other variables such as family size, average level of education, income earner and land size are also shown in the above table.

Table 4: Partial Correlation Matrix of the Explanatory Variables for Average Monthly Expenditure (AEXPEN) at Present

\begin{tabular}{|c|c|c|c|c|c|c|c|c|}
\hline Variables & AEXPEN & TSAV & LON & FS & AEDUC & AINCM & EARNER & LAN \\
\hline AEXPEN & 1.000 & & & & & & & \\
\hline TSAV & -0.021 & 1.000 & & & & & & \\
\hline LON & 0.061 & 0.000 & 1.000 & & & & & \\
\hline FS & 0.042 & -0.021 & 0.061 & 1.000 & & & & \\
\hline AEDU & 0.127 & 0.105 & -0.056 & 0.127 & 1.000 & & & \\
\hline AINCM & 0.039 & 0.045 & 0.006 & 0.039 & -0.005 & 1.000 & & \\
\hline EARNER & 0.105 & -0.174 & 0.133 & 0.105 & -0.002 & 0.019 & 1.000 & \\
\hline LAN & 0.165 & 0.059 & 0.093 & 0.165 & 0.101 & 0.056 & 0.063 & 1.000 \\
\hline
\end{tabular}

Source: calculation from Field Survey, 2017

The partial Correlation matrix of the explanatory variables for average monthly expenditure shows in table 4 that correlations are very smaller which don't have significant effect on the estimated variances and co-variances of the estimators. So it can be said clearly that though multicollinearity always exists and also does here but multicollinearity existing in this model is not problem as well as not significant.

\section{Results for OLS Regression Analysis for Expenditure Equation}

OLS Regression analysis has been use to test impact of microcredit on Living standard where average monthly expenditure is dependent variable which is influenced by some explanatory variables have been mentioned in table 5. Results of OLS Regression for average monthly 
expenditure equation have been found in table 1.5 that observes about 43 percent of variations in the dependent variable is explained the variation in independent variables integrated in case of the equation that is seen by the value of $R^{2}\left(R^{2}=0.43\right)$. The overall significance and fitness of the OLS model are checked by F-value $(\mathrm{F}=24.46)$. It indicates that the explanatory variables consistently predicted the dependent variable of the OLS model for expenditure equation. The mean value of VIF test and value of Durbin-Watson test is 1.04 and 1.88 . There were no serious problems such as multicollinearity and autocorrelation for OLS model analysis but might be existed heteroscedasticity problem in this model. The results show that the coefficient (607.792) of the variable amount of credit is positive and statistically significant of level at 1 percent with average monthly expenditure of borrower's households. This means that average monthly expenditure of borrowers' household will be increased by Tk. 607.792 if addition Tk.1000 amount of credit is increased with the loan. This additional loan may be expended for consumption including food and non food, school fee of children, medical treatment, various occasion and investment in productive sector in case of farming and non-farming activities. Other important factor is savings for poor people whose average monthly expenditure is more compared to income and savings of rich people. In economics, savings are defined as income minus consumption .The coefficient of total saving is 454.814 which is positive and statistically significant with average monthly expenditure that means that if total savings of borrowers increases, expenditure will be increased. This savings can help these people become financially secure and provide a safety net in term of emergency. The respondent of MFIs can expend in making new house, sudden loss of income, loan repayment, education, treatment etc.

Table 5: OLS Regression Analysis for Average Monthly Expenditure (AEXPEN)

\begin{tabular}{|l|l|l|l|l|}
\hline Variables & Coefficient & Std. Err. & t-ratio & Probability \\
\hline Constant & $1140.235^{*}$ & 686.733 & 1.66 & 0.098 \\
\hline Total savings $\left(\mathrm{TSAV}=\beta_{1}\right)$ & $454.814^{* * *}$ & 126.086 & 3.61 & 0.000 \\
\hline Amount of loan $\left(\mathrm{LON}=\beta_{2}\right)$ & $607.792^{* * *}$ & 100.554 & 6.04 & 0.000 \\
\hline Family size $\left(\mathrm{FS}=\beta_{3}\right)$ & -0.036 & 0.071 & -0.51 & 0.613 \\
\hline Average level of education $\left(\mathrm{AEDU}=\beta_{4}\right)$ & $0.017^{* * *}$ & 0.006 & 2.63 & 0.009 \\
\hline Average monthly income $\left(\mathrm{AINC}=\beta_{5}\right)$ & $16.774^{* * *}$ & 3.333 & 5.03 & 0.000 \\
\hline Number of income earners $\left(\mathrm{ERNR}=\beta_{6}\right)$ & 137.499 & 174.903 & 0.79 & 0.433 \\
\hline Land Size $\left(\mathrm{LAN}=\beta_{7}\right)$ & $0.018^{*}$ & 0.011 & 1.69 & 0.092 \\
\hline
\end{tabular}

Number of obs. $=198 ; \mathrm{F}(6,191)=24.46 ;$ Prob. $>\mathrm{F}=0.0000 ; \mathrm{R}^{2}$ $=0.4345 ;$ Adj $R^{2}=0.4168$; and Root MSE = 1894.4

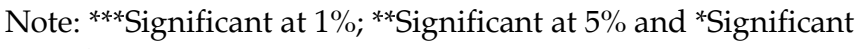
at $10 \%$

Source: Calculation from Field Survey, 2017

It is found in the above table 1.5 that the coefficients of average level of education, average monthly income and land size are statistically significant and positive relationship with dependent variable. On the other hand, the coefficients of family size and number of income earners are insignificant with dependent variable.

\section{ANOVA Test of Amount of Loan and Other main factors of living Standard}

The result of One-way ANOVA test reveals that there is statistically significant relationship between total savings (TSAV) and amount of loan at 5 percent level shown in table 1.6. Again, it is shown in the same table, the result of the one-way ANOVA test investigates that there exists statistically significant association between average level of education of borrowers' households and amount of loan at 5 percent level at present. The results of the one-way ANOVA test investigate that there exists statistically significant association among average monthly income (AINC) at 5 percent level, income earner (ERNR) at 1 percent level and total land (LAN) at 1 percent level with amount of loan from Grameen Bank (LON).

Table 6: ANOVA Test of Amount of Loan and Others such as Total Savings, Average Level of Education, Average Monthly Income, Income Earner and Land Size

\begin{tabular}{|c|c|c|c|c|c|c|}
\hline \multicolumn{2}{|c|}{} & Sum of Squares & df & Mean Square & F & Sig. \\
\hline \multirow{4}{*}{ TSAV } & Between Groups & 199155117.710 & 32 & 6223597.428 & 1.531 & 0.046 \\
\cline { 2 - 8 } & Within Groups & 670871170.800 & 165 & 4065885.884 & & \\
\cline { 2 - 8 } & Total & 870026288.510 & 197 & & & \\
\hline \multirow{4}{*}{ AEDU } & Between Groups & 212.242 & 20 & 10.612 & 1.927 & 0.013 \\
\cline { 2 - 8 } & Within Groups & 974.768 & 177 & 5.507 & & \\
\cline { 2 - 8 } AINC & Total & 1187.010 & 197 & & & \\
\hline \multirow{4}{*}{ ERNR } & Between Groups & 635077033.724 & 20 & 31753851.686 & 1.949 & 0.012 \\
\cline { 2 - 8 } & Within Groups & 2884375484.881 & 177 & 16295906.694 & & \\
\cline { 2 - 8 } & Total & 3519452518.605 & 197 & & & \\
\cline { 2 - 8 } & Between Groups & 27.521 & 20 & 1.376 & 2.042 & 0.008 \\
\hline & Within Groups & 119.292 & 177 & .674 & & \\
\hline \multirow{3}{*}{ LAN } & Total & 146.813 & 197 & & & \\
\cline { 2 - 8 } & Between Groups & 85358.294 & 20 & 4267.915 & 3.116 & 0.000 \\
\cline { 2 - 8 } & Within Groups & 242459.549 & 177 & 1369.828 & & \\
\cline { 2 - 8 } & Total & 327817.843 & 197 & & & \\
\hline
\end{tabular}

Source: Calculation from Field Survey, 2017

\section{CONCLUSION AND RECOMMENDATIONS}

Microfinance of Grameen Bank like MFIs plays a vital role in alleviating poverty and improving the living standard of borrower's households in study area of Bangladesh. The result of chi-square test in this study is shown that microfinance of GB has a positive contribution on increase savings, income, employment opportunities, assets and average level of education. It indicates and hypothesis $\left(\mathrm{H}_{1}\right)$ that microcredit has positive contribution on increase standard of living in rural poor people. On the other hand, the results of OLS regression show that microfinance of GB has positive significant impact on average monthly expenditure that indicates improved on living standard. The results of one way- ANOVA test shows that total savings of borrowers' household, number of income earners, average level of education in the borrower's households and average monthly income are also significant association with amount of loan. 


\section{Recommendations}

There are no sources in the current document.

- Obligatory savings condition should be relax in GB.

- The rate of interest should be set up with other commercial banks.

- The size of loan should be extended according to demand of loan and type of business.

- $\quad$ GB should be emphasized more on disadvantage rural area to in case of selecting respondents.

\section{REFERENCES}

Abiola I. and Salami A. O. (2011). Impact of microfinance bank on standard of living of hairdresser in Ogbomos North Local Government of Oyo State, Nigeria. International Business Management, 5(1), 27-32.

Ahmed, F., Siwar, C., Idris, N. A. H. and Begum, R. A. (2011). Impact of microcredit on poverty alleviation among rural women: A case study of Panchagarh District in Bangladesh. African Journal of Business Management, Vol. 5(16), pp. 71117119.

Alhassan A. R. and Akudugu M. A. (2012). Impact of Microcredit on Income Generation Capacity of Women in the Tamale Metropolitan Area of Ghana. Journal of Economics and Sustainable Development, ISSN 2222-1700 (Paper) ISSN 22222855 (Online), Vol.3 (5).

Ali, M. H. (2008). Evaluation of micro credit operation in Bangladesh: A critical study on Grameen Bank. Pakistan Journal of Social Science, 5(9): 960-967. ISSN: 1683-8831.

Bangladesh Bureau of Statistics (BBS), (2006) or Statistical Yearbook of Bangladesh.

Chirkos, A. Y. (2014). The impact of microfinance on living standards, empowerment and poverty alleviation of the poor people in Ethiopia, A case study in ACSI. Research Journal of Finance and Accounting. Vol. 5(13).

Coleman, B. E. (1999). The impact of group lending in Northeast Thailand. Journal of Development Economics, Vol. 60, pp. 105-141.

District Statistics, (2011): Bogra (PDF). Bangladesh Bureau of Statistics. Retrieved July 14, 2014.

Fattah S. (2014). The effect of microcredit on standards of living in Bangladesh. Princeton University, Columbia University Journal of Politics and Society.

Haque, N. (2012). The role of micro-credit to alleviate rural poverty of Bangladesh: A case study of Jagoroni Chacro Foundation. Published in Academic Research International, Vol. 2(1).

Idalor, E. and Imhanlatrimi, J. (2011). Assess and impact assessment of microfinance banks on rural poor in Nigeria: A case study of Edo State. Indian Journal of Economics and Business. 10(2-3).

Islam, M. N., Robel, K.H., Adnan, A. M. and Ekram, C. S. (2013). Do Microcredit Programs ameliorate Standard of Living?
Spotlight on Microcredit Organizations in Bangladesh. International Journal of Economics and Finance 5(4), p.109.

Juanah, M. (2005). The role of micro-financing in rural poverty reduction in developing countries: Hochschule wismar, University of technology, Business and Design, Feculty of business. WDP, Wismarer Diskussions papiere/ Wismar discussion papers.

Khan M. A and Rahman M. A. (2007). Impact of microfinance on living standards, empowerment and poverty alleviation of poor people: A case study on microfinance in the Chittagong district of Bangladesh.

Khan, M. A. and Rahman, M. A., (2007). Impact of Microfinance on Living Standards, Empowerment and Poverty Alleviation of Poor People: A Case Study on Microfinance in the Chittagong District of Bangladesh.

Kisto, M., (2014). The impact of microfinance on saving depositsthe case of Mauritius. International Journal of Recent Research in Social Sciences and Humanities (IJRRSSH), Vol. 1(1), PP. 1320.

Kuhinur S. and Rokonuzzaman M. (2009). Impact of Grameen Bank micro credit on change in livelihood status of women beneficiaries. J. Bangladesh Agril. Univ. 7(2), 381-386.

Mahmood T., Arby, M. F., Hussain T. and Sattar A. (2016). Impact of microfinance on income generation and living standards a case study of Dera Ghazi Khan Division. Pakistan Economic and Social Review. Volume 54, No. 1, pp. 73-80.

Morduch, J. (2000). 'The Microfinance Schism', World evelopment, vol. 28 no. 4 , pp. $617-29$

Noreen, U., Imran, R., Zaheer, A., and Saif, M. I. (2011). Impact of microfinance on poverty: A case of Pakistan. World Applied Sciences Journal, 12(6), 877-883.

Okafor, I. G. (2016). Microfinance banks activities and standard of Living in Nigera. IOSR Journal of Economics and Finance (IOSR-JEF), Volume 7(1). PP 01-11.

Olusanya, S. O. and Oluwatosin, O. A. (2012). Impact of microfinance bank on standard of living hairdresser in Oshodi- Isolo local government of Lagos State. IOSR Journal of Humanities and Social Science (IOSRJHSS), ISSN: 2279-0845 Volume 1, Issue 4, PP 26-35.

Public Affairs, New http://nobelprize.org/nobel_prizes/peace/yunus-lectureen.html.

Schroeder, E. (2014). The impact of microcredit borrowing on household consumption in Bangladesh. Department of Economics, Oregon State University, Corvallis, or 97331 USA.

Weerasinghe, IMS. and Dedunu, HH. (2017). Impact of microfinance on living standard with reference to microfinance holders in Kurunegala District. International Journal of Business Marketing and management (IJBMM). Volume, 2, PP. 16-23, ISSN: 2456-4559.

Yunus M., (1999). Banker to the poor: micro-lending and the battle against world poverty.

$$
--0--
$$


How to Cite: Shamim, M. (2019). Impact of Grameen Bank Microcredit on Standard of Living in Rural Poor Women in Sariakandi Upazila of Bogra District. American Journal of Trade and Policy, 6(1), 33-40.

\section{SOCIAL SCIENCE RESEARCH NETWORK}

2171 Monroe Avenue, Suite 203, Rochester, NY 14618, USA

http://www.ssrn.com/en/

SSRN Link: http://www.ssrn.com/link/American-Journal-Trade-Policy.html 